Tadeusz Linkner ${ }^{1}$

Uniwersytet Gdański

DOI: https://doi.org/10.26881/jsr.2021.16.09

\title{
ŚWIĘTY WOJCIECH W NASZEJ LITERATURZE, TAKŻE U MLODOPOLSKIEJ POETKI
}

\section{Wprowadzenie}

O św. Wojciechu w naszej literaturze pisałem już wiele razy. Zanim jednak wypowiedziałem się ten temat w ostatnim rozdziale książki $W$ misji Słowa (Linkner 1998b, s. 281-358), zapowiedziałem go już wcześniej, w 1997 r., kiedy to podałem w „Studiach Pelplińskich” wiersz Marii Konopnickiej $O$ św. Wojciechu, tak o nim pisząc:

W trudno dzisiaj dostępnym czasopiśmie „Praca” opublikowano w roku 1905 w nr 34 wiersz Marii Konopnickiej „O św. Wojciechu”. Poetka napisała go w roku 1897 z okazji 99-lecia Jego męczeńskiej śmierci, ale nie włączono go do zupełnego i pełnego wydania „Poezji” M. Konopnickiej, które ukazało się w ośmiu tomach w 1915(16) roku.

Ponieważ zbliża się 1000-letnia rocznica, więc warto przypomnieć ten utwór, którego nie sposób znaleźć w znanych i popularnych zbiorach autorki „Roty”. Należy go przypomnieć tym bardziej, że treść jednego z wersów sprawia takie wrażenie, jakoby poetka pisała go właśnie z okazji 1000-letniej, a nie 900-letniej rocznicy śmierci św. Wojciecha. I jakże tu nie wierzyć, że słowo wielkiego poety umie się zawsze znaleźć we właściwym miejscu i czasie (Linkner 1997, s. 249).

Jako że rok 1997 był rokiem millenijnym misji św. Wojciecha także dla Gdańska, w ostatnim kwartale 1997 r. przekazałem redakcji „Studiów Europejskich" artykuł dotyczący Literackiego obrazu misji św. Wojciecha z Gdańskiem w tle w powieściach Ludwika Stasiaka i Stefana Żeromskiego" (Linkner 1998a, s. 267-285), a pod koniec 1. kwartału 1998 r. dałem do pelplińskiego wydawnictwa Bernardinum książkę $W$ misji Słowa, której ostatni rozdział był rekonesansem do tematu Święty Wojciech w naszej literaturze, gdzie poza omówieniem

${ }^{1}$ tlinkner@interia.pl, https://orcid.org/0000-0001-8521-2771 
wspomnianego wiersza Konopnickiej nie mogło zabraknąć - obok takich podrozdziałów, jak $Z$ hagiografii, Bogurodzica, $W$ pamięci ludu, $W$ poezji, $W$ prozie, $W$ dramacie - wskazanego wyżej tekstu, ze Stasiakiem i Żeromskim.

Na tym jednak nie skończyły się kwerenda i słowo o św. Wojciechu w naszej literaturze. „Rekonesansu ciąg dalszy” tego tematu zaistniał w 2004 r., kiedy to udało się włączyć tak zatytułowany referat do książki Nauka społeczna Kościola, tradycja i kultura a Unia Europejska, wydanej w 2004 r. Natomiast dwa lata później, gdy okazało się to możliwe, skorzystano z ostatniego rozdziału trudno dostępnej książki $W$ misji słowa, a jego streszczenie znalazło się w „Tekach Gdańskich". Kiedy zaś udało się natrafić na nowe utwory o św. Wojciechu, zreferowano je na ogólnopolskiej konferencji Język - Szkoła - Religia w kwietniu 2009 r., by po roku można było o nich także przeczytać w pokonferencyjnej edycji. Obecnie, po ponad 10 latach, wracam do tego tematu, sięgając do kolejnych utworów, które ujawniły biblioteczne kwerendy.

Jako że nie udało się zamknąć tego tematu (a sądzę, że nierychło to nastąpi, bo co raz udaje się natrafić na literackie teksty o św. Wojciechu), tutaj zwraca się uwagę na następne utwory. Tak więc wedle chronologii należałoby powiedzieć o młodzieżowej powieści Jadwigi Papi Wielki król (Papi 1898), Michała Synoradzkiego ,podaniu dziejowym”, którego tytuł to Krwawe apostolstwo (Synoradzki 1903), następnie o Hymnie na cześć św. Wojciecha (1907) anonimowego autora, dramacie Marceliny Kulikowskiej Król Bolesław Chrobry (Kulikowska 1909), wierszu Stefanii Tuchołkowej Ofiara matki (Tuchołkowa 1914a) oraz impresji Sen św. Wojciecha (Tuchołkowa 1914b) i także tej autorki powieści Goraj (Tuchołkowa 1916), czy wreszcie o dramatach Jana Bełcikowskiego Za Bolestawa Chrobrego (Bełcikowski 1925) i Cyryla Danielewskiego Z gniazda orłów biatych, czyli rok 997 (Danielewski 1928). Ponieważ jednak w obecnej sytuacji pandemia nie pozwala bezpiecznie odwiedzać naukowych czytelni, a zbiory internetowe okazują się jeszcze zbyt ubogie, zajmiemy się tu jedynie dramatami S. Kuczyńskiego (1901) i M. Kulikowskiej - Hymn na cześć św. Wojciecha oraz utwory C. Danielewskiego i S. Tuchołkowej przełożywszy na później.

\section{Księdza Stanisława Kuczyńskiego Miłość zwycięża}

Dramat Miłość zwycięża ks. Stanisława Kuczyńskiego (1901) zapowiedziałem już w książce $W$ misji Słowa (Linkner 1998b), tu natomiast powiemy o nim więcej. Pełny jego tytuł brzmi: Miłość zwycięża. Obrazek dramatyczny z pierwszych wieków chrześcijaństwa w Polsce. Ten trzyaktowy dramat jak na „obrazek dramatyczny” jest dosyć obszerny. Akt pierwszy dzieje się na dworze króla Bolesława Chrobrego, akt drugi - przed posagiem słowiańskiego boga Lela, 
a trzeci - „,na zamku Poboga”. Jako pierwszą osobę wymienia się w tym dramacie św. Wojciecha - i ma to swoje znaczenie. Wszak rozpoczyna się tutaj od rozmowy Bolesława Chrobrego z biskupem, którego król prosi, by został na ziemi Polan. Św. Wojciech jednak, chociaż wie, że w Gnieźnie ma powstać arcybiskupstwo, jako „metropolia wszystkich biskupów słowiańskich” (Kuczyński 1901, nr 18, s. 349) nie wyraża zgody, mówiąc: „lecz mnie wola Boża gdzie indziej przeznacza, pójdę z tym głosem nieść dobrą nowinę zbawienia nieszczęśliwych pogan..." (Kuczyński 1901, nr 18, s. 349).

Ukochał jednak polski lud, bo jest wierny Bogu i nie ma w nim zdrady, której - jak wiemy - doświadczył w rodzimych Czechach, więc myśli na dworze Bolesława czas jakiś jeszcze zostać. Wie przecież, że w Lechii nie ma wielu kapłanów, a na Śląsku oraz w okolicach Krakowa trwa nadal pogańska wiara (ale nie tylko tam, bo podobnie jest w Wielkopolsce). Właśnie Bolesław Chrobry dowiaduje się od Stoigniewa, że poganin Pobóg spalił w okolicy zamieszkałą przez chrześcijan osadę, napadł na dworzec Kaniowy, porwał jego córkę i zniszczył krzyż. Wobec tego zapada decyzja, by zbrojnie nań wyruszyć, sprowadzić na królewski dwór i zmusić do przyjęcia chrztu. I wtenczas św. Wojciech postanawia odwiedzić Poboga „ze słowem miłości” (Kuczyński 1901, nr 18, s. 251).

Tyle w akcie pierwszym. W akcie drugim natomiast poznajemy pogańskie uroczysko, na którym rośnie stary, próchniejący już dąb. Obok drzewa stoi wyciosany z drewna posąg Lela, przy którym składane są objaty. Kapłani - Horno i Zyrkan - już wiedzą, że Poboga odwiedzi św. Wojciech, który przybył do Gniezna z Rzymu. Boją się tego, ponieważ Lel oraz bogowie będą się za to mścić, a ich gniewu doznają najpierw oni: kapłani i wróżbici zarazem (Kuczyński 1901, nr 19, s. 369). Wierny wierze ojców Pobóg odwiedza kapłanów wraz z porwaną córką Stoigniewa, Różaną, którą ongiś swatał ze swoim synem, Dobrosławem, a którą teraz myśli ukryć u wróżki Panichy - i dowiaduje się od nich o wizycie św. Wojciecha. Wtenczas podczas czynionych przez Horna wróżb okaże się, że sparaliżowany Dobrosław wyzdrowieje, jeżeli tylko św. Wojciech zginie. Pobóg jednak nie zechce zabić Wojciecha, stary zwyczaj Polan zabrania bowiem czynić jakąkolwiek krzywdę gościowi (Kuczyński 1901, nr 19, s. 370). Wobec tego kapłani proponują, aby sproszono lud na ucztę i wtenczas bogowie sami ukarzą św. Wojciecha.

Podczas uczty, którą mamy w trzecim akcie, pogański kapłan rozpowiada gościom, że św. Wojciech przybywa na ucztę tylko dlatego, aby zabić Dobrosława. Kiedy więc się pojawia i gdy tylko zaczyna brzmieć pieśń Bogurodzica, Horno wsypuje do jego kielicha truciznę, by potem, częstując nim gościa, pomyśleć: „To podarunek od twego dawnego ucznia, któregoś niby nawrócił, cny Adalbertusie" (Kuczyński 1901, nr 20, s. 390). Co prawda widzi to Dobrosław, ale Horno nie przejmuje się tym, wszak złożony chorobą syn Poboga jest bezsilny. Tymczasem św. Wojciech, nie poznawszy swego ucznia, który w progu się 
od niego odwrócił, oznajmia Pobogowi i ucztującym, że przychodzi do nich „ze słowem miłości” (Kuczyński 1901, nr 21, s. 409). Zamiast wypić wino, prosi tylko o chleb i wodę. Niemniej gdy tylko podnosi kielich do ust, Dobrosław, chcąc prawdopodobnie go ostrzec, wypada z łoża, a wtedy ,Jednocześnie puchar pęka w ręku św. Wojciecha i woda rozlewa się po stole" (Kuczyński 1901, nr 21, s. 409). Wtenczas Pobogowi zdaje się, że syn ujrzał śmierć, i decyduje się poprosić św. Wojciecha, by go uzdrowił. I tak się staje, gdy tylko biskup błogosławi Dobrosława krzyżem.

Pomijając takie zdarzenia w scenie szóstej trzeciego aktu, jak pobicie Zyrkana przez pachołków Horna, którzy na jego żądanie zorganizowali zasadzkę na św. Wojciecha, ale go z nim pomylili, czy uwolnienie Różany, wobec cudownego uzdrowienia Dobrosława wszyscy zebrani wraz z Pobogiem decydują się przyjąć wiarę Chrystusa, Horno zaś trafia do lochu. Wobec tego dramat kończą takie słowa św. Wojciecha: „Bracia, Bóg jest miłością, z miłości przyszedł na ten świat, z miłości umarł za nas i miłować się wzajemnie rozkazał. Miłość zawsze zwycięża! Przynieście wody ze zdroju, a odrodzę tego ostatniego kapłana pogańskiego ku żywotowi wiecznemu!" (Kuczyński 1901, nr 21, s. 410).

Wiadomo, że „obrazek dramatyczny” Kuczyńskiego ma przede wszystkim charakter dydaktyczny i moralizatorski, więc nie można się po nim spodziewać specjalnego artyzmu. Oczywiście najważniejszą postacią jest tutaj św. Wojciech $\mathrm{z}$ jego chrystianizacyjną misją. Aby jednak została ona spełniona, trzeba było niewiernych nawracać. Należało więc rozpocząć od pogańskich kapłanów, pełniących służbę przy posągu Lela. Tylko że to bóstwo nie znaczyło w słowiańskim panteonie zbyt wiele i gdyby autor tego dramatu o tym wiedział, nie przypisałby mu naczelnej roli. Pewnie o Lelu dowiedział się z mitologii Joachima Szyca (1865, s. 17), która wtenczas była najbogatsza w słowiańskie bogi i demony. Tu bodaj dlatego przywołany został ten bóg - bo chociaż pilnował wschodu słońca i porannej jutrzenki, to miał w opiece młodożeńców (Linkner 2018, s. 45). Wszak pewnie weselem skończy się w tym dramacie wątek miłosny Dobrosława i Różany. Niemniej, jak już powiedziałem, Lel niewiele znaczył i jeżeli tylko jemu oddawali cześć poddani Poboga, to nie mieli silnego opiekuna, broniącego ich przed nową wiarą. Ponieważ w tym dramacie najważniejsze jest zwycięstwo nowej wiary nad starą, trzeba powiedzieć, że autor dramatu popełnił błąd, nie przydawszy niewiernym wobec św. Wojciecha równie silnego obrońcy.

Oczywiście nie można było przemilczeć w tym dramacie słowiańskich wierzeń, bo kogo by wtenczas św. Wojciech miał nawracać. O ile jednak wystrój uroczyska jest tu niezmiernie ubogi, bo mówi się tylko o posągu Lela i objatach, o tyle jedynie rosnący tam spróchniały dąb ma swoje znaczenie, symboliczne oczywiście, gdyż wskazujące na finał dawnej wiary. Jeżeli nawet przejął to Kuczyński z Kraszewskiego, który w Kronikach historycznych właśnie dąb czynił symbolem „,inwolucji słowiańskich wierzeń” (por. T. Linkner 2014, s. 277-293), 
to tylko dobrze to mogło o nim świadczyć - podobnie jak i to, że został tu wprowadzony wątek pogańskich kapłanów i Poboga, sprzeciwiających się chrześcijańskiemu władcy i Bolesławowi Chrobremu. Nieudana próba otrucia św. Wojciecha podczas uczty za bardzo, co prawda, przypomina kruszwicki epizod, a nadto okazuje się zbyt teatralna (podobnie jak to cudowne uzdrowienie Dobrosława), niemniej scena nawrócenia Poboga i jego dworu jest, jak na tego rodzaju ludowy dramat, naturalnie zrozumiała. Podobnie jak i to, że dobro zwycięża tutaj zło, Horno bowiem za swój czyn zostaje ukarany, a drugiego z pogańskich kapłanów św. Wojciech chrzci, co ma być przykładem dla innych - mających się rychło nawrócić. Uwierzył też Pobóg, którego imię przestało już być tak wymowne, gdyż odtąd nie po Bogu jemu będzie, ale z Bogiem. Także miłość Dobrosława i Różany staje się wreszcie szczęsna; jego nawrócony ojciec okazuje się bowiem córce chrześcijanina Kaniowy przychylny - i wedle tytułu dramatu Mitość zwycięża. Oczywiście, za sprawą św. Wojciecha i wedle chrześcijańskiej religii.

Jako że to dramat ludowy, zrozumiały jest jego niski styl, chociaż autor, ks. Stanisław Kuczyński, wykazał się dramaturgicznym talentem, czytelnym nie tylko w dynamicznej akcji, ale także w scenerii, zapowiadanej w każdym akcie didaskaliami, które wedle młodopolskiej mody okazały się dosyć obszerne i dość trafne w swej kolorystyce, co zda się nawet wskazywać na młodopolski ekspresjonizm. Stąd w pierwszym akcie na dworze króla Bolesława Chrobrego komnatę u okien i drzwi zdobią szkarłatne zasłony, a przy okrytym szkarłatnym suknem stole mamy złocisty zydel. Oczywiście, jak to w średniowieczu, w kominie buzuje ogień, a na ścianach wiszą dywany, skóry niedźwiedzie, zbroje i tarcze. W drugim akcie z kolei uroczysko, przypominające scenerię ze Starej baśni Kraszewskiego, też nie kłóci się z ówczesną, XIX-wieczną wiedzą o średniowieczu - podobnie jak piastowski wystrój mieszkania Poboga, gdzie stół jest zasłany białym, pewnie lnianym obrusem, a na nim znajdują się chleby i miód w gąsiorkach. Oczywiście na ścianach mamy scenerię podobną jak w innych dramatach o średniowiecznej tematyce, czyli broń, tarcze, jelenie rogi i skóry.

\section{Marceliny Kulikowskiej Król Bolestaw Chrobry}

Kolejny dramat mówiący o św. Wojciechu to Marceliny Kulikowskiej Król Bolesław Chrobry, nazwany ,poematem dramatycznym”. Chociaż ten gatunek pomimo kilku autorskich tego rodzaju wskazań (por. Waligóra 1993, s. 117) w Młodej Polsce nie był zbyt częsty, to notujemy jego wydanie we Lwowie w 1909 r. Ponieważ poprzednio św. Wojciech występował w spisie osób dramatu jako pierwszy, teraz będzie trzeci - po Bolesławie Chrobrym i Mieszku II można więc się spodziewać, że tutaj nie będzie znaczył tyle, co poprzednio. To 
zrozumiałe, zważywszy na to, że autorka nie była specjalnie oddana religii, a więcej znaczyła dla niej modernistyczna idea Młodej Polski, co widoczne jest w treści tego dramatu, i to szczególnie w jego części trzeciej. Trzeba jej jednak oddać obiektywne potraktowanie historycznych zdarzeń; części pierwszej nadała tytuł Koronacja, drugiej - Święty Wojciech, a dopiero trzeciej - Śmierć.

W pierwszej części wojowie, oczekujący przed gnieźnieńskim tumem na koronację Bolesława Chrobrego, spodziewają się, że król poprowadzi ich na Kijów, Czechy i Pomorze. Kmiecie natomiast rozpaczają, że ginie ich dawna wiara, o czym nie pozwala zapomnieć Mściwój pochodzący z pomorskiego plemienia Wilków. Chociaż jego udaje się wojom uspokoić, to chór kmieci śpiewa tak:

Goreje nam wspomnienie,

W łunę się jarko wiąże,

Tyś Wolę zabrał naszą,

Polański, silny książę!

Tyś Bogi wziął - a kazał

Czerńców - księżami zwać

I oddać im gontyny,

I krzyże w ziemię wsiać!

Wiar naszych prawych, dawnych,

Skończony dla nas dzień!...

W Kupały noc nabożną

$\mathrm{Z}$ martwych powstaje cień!

Gdy Ładzie modły szlemy,

I ognie święte palim,

Książąt i krzyże klniemy,

Nad sobą się rozżalim...

Wspomnienia gonim dawne,

I ojców naszych wiary,

I Bogi wszystkie sławne,

I niesiem im ofiary..."

(Kulikowska 1909, s. 12-13).

Chór kończy śpiew tak, jak rozpoczął: „Wola nam zaklęta” (Kulikowska 1909, s. 13). Takie wskazanie właśnie Woli, pisanej tu nadto wielką literą, a w ostatnim wersie oznaczonej nawet czerwoną czcionką, ma swoje znaczenie. Chodzi tu o zniewolenie i odebranie wolności, to zrozumiałe, ale w młodopolskim czasie, zainteresowanym tak bardzo psychiką, znaczy to jeszcze, że wobec nowej wiary 
nie można już myśleć tak samo jak dawniej. Kiedy więc powiedzą, że zaklęta ich Wola, można to rozumieć dwojako, bo zarówno jako ,zaklętą” przed nową wiarą, jak wobec starej wiary przez nową - zniewoloną, obezwładnioną.

Kiedy podczas królewskiej uczty Bezbraim, broniąc Mściwa, zabija woja, Bolesław Chrobry każe go wypędzić - nie tylko od stołu, ale także z królestwa. Natomiast gdy wiodąca dożynkowy korowód Dubrawka obdarza żytnim wieńcem króla i Mieszka, odpędza ją zazdrosna o nią Rycheza, ponieważ - podobnie jak z nią - syn Chrobrego ma syna z Dubrawką. Tylko że król Bolesław Chrobry uważa właśnie Mieszka za swego następcę, Bezprym bowiem popiera niewiernych Lutyków. I to wszystko pozwala wiedzieć, co dzieje się nie tylko w królestwie, lecz także na królewskim dworze, gdzie aura jest taka jak wymowa tejże pieśni wojów niosących do Tumu zwłoki zabitego przez Bezbraima rycerza. Ponieważ monotonny dźwięk dzwonu jest w tej recytacji tak schopenhauerowsko młodopolski, tym bardziej trzeba go usłyszeć - zwłaszcza że później zabrzmi raz jeszcze w finale pierwszej części, co nada mu szczególne znaczenie, kiedy w części trzeciej będziemy świadkami śmierci Bolesława Chrobrego:

Klekoce dzwon żałobny,

Klekoce dzwon...

Na cztery wieści strony

Rycerza skon...

Zimne niesiemy zwłoki,

Do wiecznych bron...

Zaśpiewał nam martwotę

Żałobny dzwon...

Zaśpiewał nam martwotę

Ułudny los...

Hej! Gubi ziarno złote

Podcięty kłos...

(Kulikowska 1909, s. 29)

Tu jednak najważniejsza jest dla tego tematu cześć druga dramatycznego poematu, poświęcona św. Wojciechowi. Otóż na leśnej polanie, gdzie ongiś była gontyna, stanął krzyż. Przy nim spotykają się Mieszko i Dubrawka, prowadzący ze sobą dialog wpierw miłosny. Później możemy się z niego dowiedzieć, że Mieszko, mający za żonę Rychezę, myśli wprowadzić na dwór swego nieprawego syna, chociaż jego matka jest poganką.

Wkrótce potem w tym samym miejscu gromadzą się kmiecie. Podżegani przez człowieka z plemienia Wilków, buntują się przeciwko Bolesławowi Chrobremu, który walczy z wiarą ich ojców, i ostatecznie niszczą krzyż. Kiedy zastaje ich 
przy tym powracający z polowania król, rozkazuje jednego zabić, a na miejscu zwalonego krzyża postawić klasztor. Chociaż bowiem, jak mówią kmiecie, jest już stary, to jeszcze ma tyle sił, by wydawać tak srogie rozkazy, a nadto ma jeszcze tyle siły, by złamać pokaźną wiązkę gałęzi, co przypomina czyn Świętopełka.

Symboliczne to wobec jego słów, że nie ulegnie tym, którzy przeciwko niemu się buntują. Oczywiście myśli przede wszystkim o pamiętających i kultywujących dawne wierzenia. Chociaż bowiem minęło już wiele lat, kiedy to nad Gopłem przyjęto chrzest, to wiary ojców jeszcze wielu się nie wyrzekło. Tylko że nie ma już między nimi św. Wojciecha - zamordowali go Prusowie. Niemniej Kulikowska właśnie wtedy zdecyduje się go przywołać, czy wręcz wywołać - niczym podczas popularnego w Młodej Polsce spirytystycznego seansu:

I wtedy to z wyżyn niebieskich spływa na ziemię postać Św. Wojciecha. Suknia jego długa, biała, w ręce - pastorał, na głowie infuła biskupia... twarz blada... włosy i broda jasne, oczy wypełnione tęsknotą. Postać to szczupła, chuda nawet. Zatrzymuje się Św. Wojciech przy leżących na ziemi szczątkach krzyżowych i tak wyżej od Króla stoi (Kulikowska 1909, s. 85).

Jakby tego było jeszcze mało, św. Wojciech powiada po młodopolsku, że przybył do „duszy Króla” (Kulikowska 1909, s. 86). Kończy się już jego żywot i przyjdzie mu wkrótce, jak każdemu, spocząć w mogile (Kulikowska 1909, s. 86-87). Wobec tego czym są wszelkie dokonania, jeżeli „próchna leżą w każdym czynie" (Kulikowska 1909, s. 89), co jak najbardziej przypomina barokowe vanitas vanitatum et omnia vanitat z Wulgaty, bo przecież baroku w Młodej Polsce mamy zawsze wiele. Bolesław Chrobry powinien więc żałować za swe czyny. Św. Wojciech bowiem, trzymający niczym Chrystus „drzewce” krzyża, powie, że w nich „krwawe były rany” (Kulikowska 1909, s. 91). Dowodzą tego zarówno wygnanie żony Mieszka I, Ody, i jego braci - Mieszka, Świętopełka i Lamberta (Kulikowska 1909, s. 91-92) - jak i okaleczenie krewnych: Odylena i Prybuwoja, którym „wyłupiono oczy” (Kulikowska 1909, s. 92), a wreszcie wypędzenie żon: Judyty i Emnildy. Wszak wszystkie te postaci pojawiają się przed Bolesławem jako Cienie - po młodopolsku. Co prawda Chrobry był wtenczas młody i władzy nigdy nie chciał się pozbyć:

Sam - w ziemi całej chciałem stać,

Sam w Woli własnej chciałem trwać,

- By w dół nie opaść - wznieść się trzeba

(Kulikowska 1909, s. 95). 
Stojąc już jednak nad grobem, Bolesław Chrobry pojmuje - dzięki napomnieniom św. Wojciecha - czynione ongiś zło (zob. przypis w: Waligóra 1993, s. 106), lecz nadal nie myśli rezygnować z orężnej walki, której symbolem jest jego miecz - Szczerbiec. Musi jednak pamiętać o bliskiej śmierci, bo przecież „Kwiat spada w jesiennej porze" (Kulikowska 1909, s. 103), jak powie, ginąc w obłoku, św. Wojciech.

Kiedy ta wizja się kończy, Bolesław Chrobry zostaje sam przed tymże zniszczonym krzyżem. Co prawda ożywia się, kiedy jego rycerze nadchodzą i zakładają mu zbroję, jednak jest tak słaby, że sam już nie wyruszy na bój. Na tym jednak nie kończy się druga część tego dramatu, gdyż finalizujące ją didaskaliaco stanowi pewnego rodzaju novum w tej dramaturgicznej kompozycji - wprowadzają do obrazu trzeciego. Jak bowiem poprzednio didaskalia zapowiadały miejsce i czas koronacji oraz uroczysko, gdzie na miejscu gontyny stanął krzyż, tak tym razem ukazują taką scenerię:

Wielka komnata w zamczysku królewskim. Po lewej stronie łoże, na którym Król stary dogorywa. Po prawej komin, w nim dymią przyćmionym płomieniem wielkie szczapy jodłowe. Podle komina czterech starców radnych: dwaj z nich - ci sami, co Króla osłabłego wiedli. Cisza... (Kulikowska 1909, s. 109).

Obraz trzeci, którego tytuł to Śmierć, inicjuje chór Starców i wprowadza w tanatyczną aurę agonii Króla, przepowiadaną wcześniej przez św. Wojciecha:

Czeka grób... czeka grób...

Mogiła...

Ginąć... ginąć w Nicoście...

W ziemię położyć koście...

Zetliła się pochodnia... zetliła...

(Kulikowska 1909, s. 109-110)

Tylko że zanim nadchodzi śmierć, wpada do komnaty rycerz z koroną i Szczerbcem w rękach, wzywając króla do boju, gdyż z wygnania wrócił brat Mieszka. Na nic to jednak, bo władcy braknie już sił. Zresztą nieprzychylna wojnie z Wilkami i Lutykami jest posłuszna cesarzowi Rycheza. Kiedy zaś wychodząc, spotyka ona w drzwiach Mieszka prowadzącego Bolka, nieślubnego syna Dubrawki, i zabrania im wstępu, słyszy od męża: „To syn słowiańskiej mej żony!”. Znamienne to słowa, zabrzmi w nich bowiem uznanie nie tylko dla słowiańskości, z którą Chrobry się utożsamia, ale także dla dawnych wierzeń, nie mówiąc już o negacji germańskości. Pozwala to wiedzieć, że ich pierworodny syn, w którym płynie krew niemieckiej matki, powinien przed synem Dubrawki ustąpić. Lud pragnie wrócić do wiary ojców, więc Mieszko, uznając Bolka za 
swego prawowitego syna, jakby się na to godził. To jednak nie wszystko, bo przy łożu umierającego króla staje żądający korony, wygnany przezeń Bezprym. Chociaż zda się, że tego wszystkiego w tej scenie za wiele, to jest to przemyślane, na tyle bowiem zasłużył sobie Chrobry w chwili śmierci.

Po jego śmierci natomiast słyszymy trzy Głosy dotykające ostatecznego finału człeczego żywota, który zapowiadał właśnie św. Wojciech. Taki zamysł Kulikowskiej, starającej się wedle tytułu trzeciej części kierować uwagę przede wszystkim na śmierć, okazuje się udany. Wobec tego pierwszy Głos powiada, że każdemu pisana jest śmierć:

Człowiekiem życie kolebie,

Jak kłosem z pół!

I każdy w ziemi polęże

Jeniec czy król...

(Kulikowska 1909, s. 126),

następny - że wobec śmierci nie ma znaczenia, co się w życiu osiągnęło:

Człowiek jak ptak polata w górę,

I skrzydłem nowych szuka prób!

Wzbił się, wybujał ponad chmurę

- - A wraca w grób... a wraca w grób...

(Kulikowska 1909, s. 127),

ostatni zaś - że jeżeli nawet umierająca jednostka się buntuje, to i tak musi ustąpić wobec nieszczęsnego finału człowieczej egzystencji, chociaż uczucie ma znaczenie:

Czemu ty czarne nieszczęście

Chodzisz po świecie?

I czemu ciebie ziemia nie pożre

Ogień nie spali?

I wiatr nie zmiecie?...

Przed Tobą życie wszelkie się trwoży...

Radość przygasa

I w dal ucieka...

A tyś obrało jedno mieszkanie:

SERCE CZŁOWIEKA

(Kulikowska 1909, s. 127).

Na nic to jednak wobec tegoż wszechmocnego nieszczęścia, któremu nie można zapobiec i o którym nie można zapomnieć, jako że to konieczny finis 
każdego żywota. Takie są bowiem ostatnie słowa tego dramatycznego poematu, które odnoszą się nie tylko do śmierci Bolesława, ale także do każdego, i bodaj najbardziej do autorki tych słów, która kilka lat później doznała tegoż „,czarnego nieszczęścia” śmierci, popełniwszy samobójstwo. Czyżby zatem ten trzeci Głos miał być tego zapowiedzią?

Pomijając nawet tę interpretację, którą mimo wszystko wspomaga oczywiste zdarzenie, powinno się w tym miejscu pamiętać o dekadentyzmie, kiedy to śmierć znaczyła wiele. Ale ponieważ to „Rok 1908 Luty - Sierpień”, już nie ten czas. Znając jednak finał żywota Kulikowskiej, nie można o tym zapomnieć, podobnie zresztą jak o tymże „Krakowie - Zakopanem”, gdzie dramat ten powstawał. Tak wiec raz jeszcze trzeba powtórzyć, że śmierć znaczy tu wiele - wiele więcej niż miłość. Dlatego też św. Wojciech zwraca uwagę głównie na śmierć. Przecież nie dlatego ukazuje się Bolesławowi Chrobremu, aby pochwalić go jako obrońcę chrześcijańskiej wiary, ale by przypomnieć mu właśnie o bliskiej już śmierci.

Niemniej ówczesne krytyczne uwagi tego specjalnie nie dotyczyły. Bronisław Chlebowski zainteresowanie Kulikowskiej w tym dramacie przeszłością widział w aurze Krakowa oraz w uwadze autorki skupionej na Wyspiańskim. Ponieważ bliżej mu było do pozytywizmu, negatywnie ocenił duchowe treści Króla Bolestawa Chrobrego (Chlebowski 1910, s. 69). Tymczasem anonimowy autor zwracał uwagę na chóry „uzewnętrzniające” sytuację psychiczną bohaterów oraz na „prawdy wszechludzkie”, wybrzmiewające chociażby ze słów: „Człowiek się mocą własną poi, / I wierzyć chce, i wierzyć chce, / A Starość, Śmierć i Nicość stoi, / Ach! Powiew Nicości czynom śle...” (anonim 1901). Ponadto tenże recenzent dostrzegał w dramacie o wygłosie tragedii uznanie dla dokonań Bolesława Chrobrego, uwieńczonych królewską koroną. Zwracał też uwagę na to, jak dzieło Bolesława Chrobrego poczęło się „rozprzęgać” po jego śmierci. Kończył zaś omówieniem dramatu Kulikowskiej, którego nie powinno się tego pominąć:

Jest w „Królu Bolesławie” coś z tego nurtu snów o przeszłości, co źródło swe u niebotycznych szczytów Króla Ducha wzięły, potem długo rozlewały się skrycie po dnach duszy polskiej, by ostatnio wypłynąć w Wyspiańskim, Micińskim i plejadzie pomniejszych, - lecz ponadto jest w tym poemacie dramatycznym indywidualny ton rezygnacji smutnych, melancholijnych i rzeczywistych, jest język udatnie (z małymi wyjątkami) a swoisto stylizowany, jest duże opanowanie formy i wiele pięknych lirycznych dywersji..." (anonim 1909).

Tymczasem jakie było zdanie samej autorki o dramacie Bolesław Chrobry, mamy okazję dowiedzieć się z jej wspomnień; 24 lutego 1908 r., podobnie jak tenże anonimowy recenzent, pisze o znaczącej roli Chóru, starając się przy tym oddać aurę tego czasu: 
Pracuję obecnie nad dramatem „Bolesław Chrobry”. Pracuję, jak zwykle, powoli i mozolnie. Forma dramatu wierszowanego, gdzie by chór oddawał nastrój, gdzie by się nie rozmijać zbyt brutalnie z pewną, względną treścią historyczną, przedstawia dla mnie dość trudności Nie mogę się posługiwać mową ludową, pojęciami, przenośniami dzisiejszymi. Postawiłam sobie, jako zadanie, prostotą i siłą wywołać nastrój minionej, barbarzyńskiej epoki (Kulikowska 1912, s. 128).

To tyle o św. Wojciechu w dramacie Marceliny Kulikowskiej, w którym modernistyczna myśl Młodej Polski nie pozwoliła specjalnie wyeksponować chrześcijańskich treści, kierując głównie uwagę na Bolesława Chrobrego i jego śmierć oraz na miłość jego syna do wiernej dawnym bogom Dubrawki. Miłość i śmierć, a wreszcie dawne wierzenia wiele bowiem znaczyły w myśli młodopolskiej. Co prawda św. Wojciecha w spisie osób dramatu wyprzedził Bolesław Chrobry, ale tylko dlatego, że za tak silną osobowością tęsknili zarówno ówczesny artysta, jak i zniewolona zaborami Polska. Ponadto u Kulikowskiej ma swoje znaczenie owa pisana wielką literą i częsta Wola, natomiast św. Wojciech nie wypowiada się negatywnie o broniących dawnej wiary, ale przede wszystkim gani złe czyny Bolesława Chrobrego, nakazując mu zwłaszcza pamiętać o śmierci. Jak to bowiem w Młodej Polsce, silna i niezłomna jednostka znaczy tu wiele. Ponieważ jednak zwycięża ją śmierć, wiadomo, że Kulikowska będzie o niej mówiła tak często, jak często pamiętano o śmierci w dekadentyzmie. Kieruję na koniec uwagę właśnie na Króla Bolesława Chrobrego, ponieważ wśród tych utworów jest on najlepszy - artystycznie i kompozycyjnie - chociaż nie mówi tyle o św. Wojciechu co dramat Kuczyńskiego Miłość zwycięża.

\section{Bibliografia}

[anonim] (1910), Rec. M. Kulikowska, ,Król Bolestaw Chrobry...,”, „Literatura i Sztuka" nr 18.

Bełcikowski J. (1925), Za Bolesława Chrobrego, Poznań.

Chlebowski B. (1910), Rec. M. Kulikowska, „Król Bolestaw Chrobry...”, „Książka” nr 2.

Danielewski C. (1928), Z gniazda ortów białych, czyli rok 997. Obraz dramatyczny w 4-ech aktach, Poznań.

Hymn na cześć św. Wojciecha (1907), „Przewodnik Katolicki” nr 16.

Kuczyński S. (1901), Miłość zwycięża. Obrazek dramatyczny z pierwszych wieków chrześcijaństwa w Polsce, „Kronika Rodzinna” nr 18-21.

Kulikowska M. (1909), Król Bolestaw Chrobry. Poemat dramatyczny, Lwów.

Kulikowska M. (1912), Z dziejów duszy, Kraków. 
Linkner T. (1997), Wiersz Marii Konopnickiej o św. Wojciechu, „Studia Pelplińskie" t. XXVI.

Linkner T. (1998a), Literacki obraz misji św. Wojciecha z Gdańskiem w tle w powieściach Ludwika Stasiaka i Stefana Żeromskiego, „Studia Europejskie” t. 2, Torun.

Linkner T. (1998b), Święty Wojciech w naszej literaturze - rekonesans, w: tenże, $W$ misji Stowa, Pelplin.

Linkner T. (2014), W romantycznym kręgu słowiańskich wierzeń, Gdańsk.

Linkner T. (2018), Słowiańskie bogi i demony. Z rękopisu Bronisława Trentowskiego, wyd. 3, Gdańsk.

Papi J. (1898), Wielki król. Powieść dla młodzieży z czasów Bolesława Chrobrego, Petersburg.

Synoradzki M. (1903), Krwawe apostolstwo (z cyklu „Nasze podania dziejowe"), Warszawa.

Szyc J. (1865), Słowiańscy bogowie, Warszawa.

Tuchołkowa S. (1914a), Ofiara matki, „Przewodnik Katolicki” nr 16.

Tuchołkowa S. (1914b), Sen św. Wojciecha, „Przewodnik Katolicki” nr 16.

Tuchołkowa S. (1916), Goraj. Powieść na tle czasów Mieszka I i Bolestawa Chrobrego napisana w 950 rocznice zaprowadzenia chrześcijaństwa $w$ Polsce, t. 1-3, Poznań.

Waligóra J. (1993), Dramat historyczny w epoce Młodej Polski, Kraków.

Streszczenie

\section{Święty Wojciech w naszej literaturze, także u młodopolskiej poetki}

To kolejny rozdział pracy o św. Wojciechu w naszej literaturze. Tym razem mamy tu o dramatach S. Kuczyńskiego Miłość zwycięża i M. Kulikowskiej Król Bolesław Chrobry. W obu mówi się o dawnych wierzeniach, z którymi zmaga się św. Wojciech, ale najwięcej jest na ten temat w pierwszym utworze, artystycznie jednak słabszym od dramatu Kulikowskiej. U niej św. Wojciecha interesuje nie tyle zmaganie nowej wiary ze starą, ile sytuacja umierającego króla. Wszak śmierć i miłość interesowały Młodą Polskę - a Kulikowska była właśnie jej poetką.

Słowa kluczowe: Pobóg, Lel, św. Wojciech, Bolesław Chrobry, Mieszko jego syn, Dubrawka, Rycheza, śmierć i miłość 


\section{Summary \\ Saint Wojciech (Adalbert of Prague) in our literature, also in the works of a Young Poland poet}

This is the next chapter of the work on St. Wojciech in our literature. This time we are talking about the dramas of S. Kuczyński "Miłość zwycięża" and M. Kulikowska "Król Bolesław Chrobry". Both speak of old beliefs that St. Wojciech, but most of it is on this subject in the first, but artistically weaker than Kulikowska's drama. With her, St. Adalbert is not so much interested in the struggle of the new faith with the old one, as in the situation of the dying king. After all, Death and Love interested Młoda Polska, and it was Kulikowska who was her poet.

Keywords: Pobóg, Lel, św. Wojciech, Bolesław Chrobry, Mieszko - his son, Dubrawka, Rycheza, death and love 